\title{
Measuring the Efficiency in the Lithuanian Banking Sector: The DEA Application
}

\author{
Lina Novickytè ${ }^{1, *}$ (i) and Jolanta Droždz ${ }^{2}$ \\ 1 Division of Farms and Enterprises Economics, Lithuanian Institute of Agrarian Economics, \\ V. Kudirkos st. 18-2, Vilnius LT-01113, Lithuania \\ 2 Faculty of Economics and Business Administration, Vilnius University, Sauletekio ave. 9 (II bldg.), \\ Vilnius LT-10221, Lithuania; jolanta.drozdz@cr.vu.lt \\ * Correspondence: lina.novickyte@gmail.com; Tel.: +370-68799055
}

Received: 31 December 2017; Accepted: 16 March 2018; Published: 27 March 2018

\begin{abstract}
The purpose of this study is to examine the efficiency of the banks in Lithuania by employing the DEA method and evaluate bank performance in a low interest rate environment. The efficiency scores were calculated with a non-parametric frontier input-oriented DEA technique with the variable returns to scale (VRS) and the constant returns to scale (CRS) assumptions. Five alternative models with different input-output combinations were developed, based on production, profitability and intermediation dimensions. The main bank profitability measure-the return on assets (ROA) ratio-was employed to validate the results obtained using the DEA method. The Lithuanian bank's efficiency analysis based on the VRS assumption shows that better results are demonstrated by the local banks. The technical efficiency analysis based on the CRS assumption shows other results: the banks owned by the Nordic parent group and the branches have higher pure efficiency than local banks and have success at working at the right scale. Based on this, it stated that during the 2012-2016 period the larger Lithuanian banks (subsidiaries) applied a more appropriate business model than smaller (local) banks operating in Lithuania. Additionally, this research contributes to the scholarly literature in the field of determinants of bank business performance in concentrated markets dominated by foreign banks and, in particular, from one region.
\end{abstract}

Keywords: efficiency; banks; data envelopment analysis (DEA); input-output; non-parametric methods

JEL Classification: C14; C67; G21

\section{Introduction}

It was commonly believed that the purpose of the financial sector was to mediate the economic and investment needs of economic entities and redistribute funds between economic activities. Nowadays, well-functioning financial markets and banking institutions are usually considered to be a condition favourable to economic growth (Diallo 2018; Belke et al. 2016; Cevik et al. 2016; Zhang et al. 2016; Destefanis et al. 2014; Roghanian et al. 2012; Ferreira 2012; Balkevicius 2012; Waheed and Younus 2010). Banks, being among the most important participants in the financial system, play an important role in it. As agents, they actively contribute to the efficient reallocation of resources in the market, fund enterprise projects, thus promote economic growth, maintain long-term relationships with companies, solve the problem of information asymmetry and share risk, mitigating economic fluctuations. Diallo (2018) states that efficiency makes banks more resilient to shocks, thereby positively and significantly affecting growth. Belke et al. (2016) study show that relatively more profit-efficient banks foster growth in their region. The banks' contribution to the economic development depends on their legal status. It might be the case of developing countries, where 
state-owned commercial banks or rural credit cooperatives has no causality or rather a negative impact on GDP (Banerjee et al. 2017; Andersson et al. 2016).

However, in the same way, banks can contribute to the economic collapse of the financial system. They may become the center of a financial crisis that spreads the negative effects of the emerging crisis through close interactions with other participants of the financial system and allows them to disseminate financial contagion across the financial system. Diallo' (2018) study shows that bank efficiency relaxed credit constraints and increased the growth rate for financially-dependent industries during the crisis. This finding shows the great but overlooked the importance of bank efficiency in mitigating the negative effects of financial crises on growth for industries that are most dependent on external financing. Thus, even small shocks can trigger a significant negative impact on the entire financial system and/or the whole economy.

The importance of bank efficiency and bank market concentration has also been the object of the discussion (Ferreira 2012). Waheed and Younus (2010) provide quantitative support to the view that the financial sector's development is crucial to economic growth and the efficiency of the financial sector is potentially important to the long-term growth performance of the countries. The analysis of both, the development of the financial sector, and the dependence of the economic development makes it possible to state that there is a strong association between the development of the financial sector and the development of the economy, but the determination of quantitative assessment and the causal relationship remains an open question (Balkevicius 2012). Given this positive relation, the importance of the financial sector's development should not be underestimated and has to be one of the main strategies to achieve a sustainable economic growth in the long term.

In general, efficiency in economics is interpreted as the maximum potential ratio between the output and the input of the product development process, which shows the optimal distribution of available resources that would allow achieving the maximum potential (Cvilikas and Jurkonyte-Dumbliauskiene 2016). Drucker (1963) has practically stated the variation between effectiveness and efficiency. Drucker refers to "doing things right" as an efficiency, while the effectiveness means "doing the right things". In this definition, a measure of efficiency appraises the organization's ability to achieve the output considering the minimum input level. Efficiency and scale economies are known as two critical elements governing productivity in the banking sector (Cevik et al. 2016; Roghanian et al. 2012; Fung and Cheng 2010).

The literature on the banking sector efficiency in the emerging European countries is increasingly growing (Diallo 2018; Cevik et al. 2016; Belke et al. 2016; Ferreira 2012; Roghanian et al. 2012; Fung and Cheng 2010; Kutsomanoli-Filippaki et al. 2009). The efficiency of the banking industry influences the cost of financial intermediation and the overall stability of the financial system, as banks constitute the backbone of financial markets in the Central and Eastern European (CEE) economies. Belke et al. (2016) study show that regions with a higher intermediation quality of banks grow faster. Hence, an improvement of banking performance indicates better allocation of financial resources resulting in an increase in investment that favors growth (Cevik et al. 2016). Diallo (2018) stresses the importance of the quality of the financial sector, i.e., its efficiency. Kutsomanoli-Filippaki et al. (2009) emphasize that the efficiency of the banking sector is of vital importance from both the microeconomic and macroeconomic perspectives. The efficiency of the banking sector is crucial in terms of competition during the transition to a market economy because the number of foreign banks significantly increased in the CEE region. Their findings implied a lack of efficiency in all of the CEE countries. Furthermore, they confirmed the relationship between the ownership and bank performance, in which the foreign bank ownership provided the highest productivity gains.

The current paper deals with the subsector of credit institutions of the financial sector in Lithuania. Balkevicius (2012) provides an overview of the Lithuanian financial sector's evolution, its structure, and influence on economic development. The banking sector is considered as the most important link in the chain of financial intermediation, with the greatest weight in the financial sector. Some authors closely connect the bank sector efficiency with the risk management 
performance (Cvilikas and Jurkonyte-Dumbliauskiene 2016; Zhang et al. 2016; Chen et al. 2013). Zhang et al. (2016) indicate that financial system risk tolerance capacity has a positive effect on long-term growth. The results of the previous research carried out in this field show that the banking risk management efficiency increases with the increased size of the financial institution, but this growth is decelerating (Cvilikas and Jurkonyte-Dumbliauskiene 2016). The empirical evidence to date seems to suggest that foreign-owned banks of developing and transition countries have succeeded in capitalizing on their advantages and exhibit a higher level of efficiency compared to their domestic bank peers (Cevik et al. 2016; Sufian et al. 2016). However, domestic banks may have distinct advantages over their foreign counterparts because of the intensive accumulation of tacit knowledge in economic, social, legal, and cultural conditions in their home country market. In contrast, foreign banks may face problems in developing a deep understanding of the host country's cultural and social regulations and their impact (Sufian et al. 2016).

According to (Cooper et al. 2011) since 1985, DEA has been widely applied in the banking sector around the world. To measure bank efficiency authors (Fethi and Pasiouras 2010; Titko et al. 2014; Paradi and Zhu 2013; Asmild and Zhu 2016; Tuškan and Stojanović 2016; Cvetkoska and Savić 2017) used different application of DEA.

European banks continue to struggle with declining profitability in a low (negative) interest rate environment. Therefore, taking into account the situation in the market, banks are obliged to change their business models (to adapt to low interest rates) and to review the value chain of banking services in a search for alternative sources of income and to change the existing cost structure. The Financial Supervisory Authorities also claim that the banks may have to consider the possibility of creating a business model where the interest income would play only a minor role.

The purpose of this study is to examine the efficiency of the banks in Lithuania by employing the DEA method and evaluate bank performance in a low interest rate environment.

This study provides an empirical contribution to the concept of the efficiency research of the bank's performance. In addition, the research contributes to the scholarly literature on the field of determinants of the performance of bank businesses in concentrated markets which are dominated by foreign banks and, in particular, from one region.

The paper is structured as follows: Section 2 provides data, research constructs, and their measurement, model specification, and identification. Section 3 provides the measurement of the Lithuanian banks' efficiency and its estimation, as well as the discussion of the results. Section 4 comprises a general discussion, and conclusions are presented in Section 5.

\section{Research Data and Methodology}

Efficiency can be measured using a frontier approach. Frontier techniques can be parametric and non-parametric. DEA is a non-parametric method which means that no prior functional form is assumed for the frontier, outside of a simple assumption of piecewise linear connections of units on the frontier. DEA measures the technical efficiency with the focus on levels of inputs relative to outputs of a sample of decision-making units (DMUs). The distance between the observed data point and the frontier measures the relative inefficiency or ineffectiveness of each DMU. There are three types of basic DEA models: radial, additive, and slack-based measure models (Paradi et al. 2018). The initial DEA model, as originally presented in (Charnes et al. 1978), was built on Farrell's seminal paper "The measurement of productive efficiency" (Farrell 1957). This is a radial model characterized by the fact that the DMU's efficiency score is derived from the extent to which all of its inputs can be contracted and/or its outputs expanded (contraction/expansion occurs proportionately). The CCR model assumed that the production technology, and the so-called production possibility set, exhibited constant returns to scale (CRS). Charnes, Cooper, and Rhodes presented the model of two orientations: input- and output-orientations. The orientation corresponds to the viewpoint taken in improving the inefficient units, whether the goal is to reduce excess inputs consumed or expand shortfalls in outputs produced, respectively, to move the inefficient unit to the frontier. The CCR model was developed 
under the CRS assumption, but later model modification proposed by (Banker et al. 1984) employed the VRS assumption, as well.

According to (Cooper et al. 2011) since 1985, DEA has been widely applied in the banking sector around the world. Among these studies, $36 \%$ of the DEA models are applied with the assumption of variable returns to scale (VRS), $26 \%$ with the assumption of constant returns to scale (CRS), and $38 \%$ of studies are conducted under both the CRS and VRS assumptions. Paradi and Zhu (2013) argue, that the banking industry has been the object of the DEA analysis by a significant number of researchers and probably is the most heavily studied of all the business sectors. To measure the efficiency in the Lithuanian banking sector, we used the input-oriented DEA model with the variable returns to scale (VRS) and the constant returns to scale (CRS) assumptions. Using these assumptions or CCR model and BCC model, we can distinguish two different kind of efficiency-technical and scale efficiencies. The input-oriented model is the most frequently used in measuring banking efficiency. This choice is likely to be based on the fact that the bank managers have a higher control over inputs (labor, expenses, and etc.) rather than outputs (loans, income, and etc.) (Fethi and Pasiouras 2010; Titko et al. 2014) and they manage the bank's cost centers when making strategic decisions.

The efficiency score is estimated as the ratio of weighted outputs to weighted inputs (Charnes et al. 1978). Weights are selected for each variable of every analyzed unit in order to maximize its efficiency score. The efficiency rate for each unit of the reference set of $j=1, \ldots, n$ banks, is evaluated in relation to other set members (Charnes et al. 1978). The maximal efficiency score is 1 , and the lower values indicate the relative inefficiency of the analyzed objects.

The DEA model with $\mathrm{m}$ inputs variables, s outputs variables, and $\mathrm{u}$ DMU's, the envelopment form of the input-oriented model is given by (Charnes et al. 1978) and Cooper et al. (2007):

$$
\operatorname{maxh}_{0}(u, v)=\frac{\sum_{r} u_{r} y_{r 0}}{\sum_{i} v_{i} x_{i 0}}
$$

subject to:

$$
\begin{gathered}
\frac{\sum_{r} u_{r} y_{r j}}{\sum_{i} v_{i} x_{i j}} \leq 1 \text { for } j=1, \ldots, n, \\
u_{r}, v_{i} \geq 0 \text { for all } i \text { and } r
\end{gathered}
$$

We used transformation developed by (Charnes and Cooper 1962) for linear fractional programming. This transformation selects a solution (i.e., the solution $(u, v)$ for which $\sum_{i-1}^{m} v_{i} x_{i 0}=1$ ) and yields the equivalent linear programming problem in which the change of variables from $(u, v)$ to $(\mu, v)$ is a result of the "Charnes-Cooper" transformation:

$$
\max z=\sum_{r-1}^{s} \mu_{r} y_{r 0}
$$

subject to:

$$
\begin{gathered}
\sum_{r-1}^{s} \mu_{r} y_{r j}-\sum_{i-1}^{m} v_{i} x_{i j} \leq 0 \\
\sum_{i-1}^{m} v_{i} x_{i 0}=1 \\
u_{r}, v_{i} \geq 0
\end{gathered}
$$

For which the linear programming dual problem is:

$$
\Theta^{*}=\min \Theta
$$


subject to:

$$
\begin{gathered}
\sum_{j-1}^{n} x_{i j} \lambda_{j} \leq \Theta x_{i 0} i=1,2, \ldots, m ; \\
\sum_{j-1}^{n} y_{r j} \lambda_{j} \geq y_{r 0} r=1,2, \ldots, s ; \\
\lambda_{j} \geq 0 j=1,2, \ldots, n .
\end{gathered}
$$

This model is referred to as the "Farell model". This model is the output-oriented model that attempts to maximize outputs with the given input level.

The second is called the input-oriented model, which targets to minimize inputs while adequately satisfying the given output level (Cooper et al. 2007; Zhu 2009):

$$
\min \Theta-\varepsilon\left(\sum_{i=1}^{m} s_{i}^{-}+\sum_{r=1}^{s} s_{r}^{+}\right)
$$

subject to:

$$
\begin{gathered}
\sum_{j=1}^{n} \lambda_{j} x_{i j}+s_{i}^{-} \leq \Theta x_{i 0} i=1,2, \ldots, m ; \\
\sum_{j=1}^{n} \lambda_{j} y_{r 0}-s_{i}^{+}=y_{i 0} r=1,2, \ldots, s ; \\
\lambda_{j} \geq 0 j=1,2, \ldots, n . \\
\sum_{j=1}^{n} \lambda_{j}=1
\end{gathered}
$$

If the constraint $\sum_{j=1}^{n} \lambda_{j}=1$ is adjoined, they are known as the BCC model (Banker et al. 1984). The BCC model is also referred to as the VRS assumption and distinguished from the CCR model which is referred to as the CRS model. The VRS assumption or BCC model takes into account the variation of efficiency with respect to the scale of operation and measures pure technical efficiency. The BCC model can be used to measure the scale efficiency:

$$
\text { Scale Ef ficiency }=\frac{\text { Technical ef ficiency from } C R S}{\text { Technical ef ficiency from } V R S}
$$

The second important question to measure efficiency is the determination of adequate model variables (inputs and outputs). Cooper et al. (2011) and Paradi et al. (2018) indicate that the number of DMUs should be at least three times the total number of inputs plus outputs used in the models. Cooper et al. (2007), Cooper et al. (2011), and Cook et al. (2014) proposed a similar rule to set a minimum number of DMUs in relation to the number of variables to have a meaningful result with a clear set of efficient and inefficient units:

$$
n \geq \max \{m \times s, 3(m+s)\},
$$

where $m, s$, and $n$ are the numbers of inputs, outputs and DMU's respectively.

The performance of banks and bank branches are analyzed along three dimensions: production, profitability, and intermediation. These three dimensions reveal the main areas of the bank's activities and assess the bank's business model. Banks being the main financial intermediators must seek efficiency in resources allocation (deposits, loans, securities, etc.). Additionally, banks are profit seekers. They must effectively manage the risks in order to be profitable (net interest income, operating profit, net profit, etc.). Production approach assumes that banks used capital and other resources (tangible and intangible, human resources, etc.) to produce different banking products (for example loans and deposits). 
According to these approaches, we have constructed five models (see Table 1). These models represent all the three dimensions: production, profitability and intermediation dimensions. Models differ in the number of incorporated variables: four models with two variables, and one model with three variables. We used only one model with three variables because there are only seven DMUs in our sample. According to Cooper et al. (2011) and Paradi et al. (2018), DMUs should be at least three times larger than the total number of inputs plus outputs used in the models.

The research sample consists of six commercial banks operating at the moment in Lithuania. Branches of foreign financial institutions are included in the sample as one aggregated bank (financial data of foreign bank branches). This choice is due to the fact that the Bank of Lithuania publishes only the overall performance of all the branches operating in Lithuania and based on the fact that a branch office is not a separate legal entity of the parent bank. The annual banking data used for analysis was extracted from the main indicators of the banking sector activities provided by the Bank of Lithuania (2017a, 2017b, and 2017c) and the Association of Lithuanian Banks (2017) as for the period of 2012-2016.

DEA assumes all the variables to be non-negative numbers. During our analysis, all the negative numbers (values) were changed to zero.

Table 1. DEA models with different input-output combinations.

\begin{tabular}{|c|c|c|c|}
\hline Model & Inputs & Outputs & Data Sources \\
\hline M1 & Deposits & Operating profit & \multirow{5}{*}{$\begin{array}{l}\text { Bank of Lithuania (2017a, } \\
\text { 2017b, and 2017c) and } \\
\text { Association of } \\
\text { Lithuanian Banks (2017) }\end{array}$} \\
\hline M2 & Labor expenses & Loans & \\
\hline M3 & $\begin{array}{l}\text { Deposits } \\
\text { Debts to banks and other credit institutions }\end{array}$ & Profit before tax & \\
\hline M4 & Deposits & Loans & \\
\hline M5 & Deposits & Net interest income & \\
\hline
\end{tabular}

\section{Results}

The Lithuanian financial system is dominated by banks offering basic retail banking services, leasing, and insurance services. By the end of 2016, the Lithuanian banking sector comprised six banks and eight branches of foreign banks (seven of them are already operating and one preparing to launch its operations), and 73 credit unions. All the banks operating in Lithuania are retail banks or have a retail business model. At the end of 2016, all the banks' assets accounted for $79.2 \%$ of the total financial system.

The banking sector is dominated by foreign capital banks (see Table 2). Three of the subsidiaries of foreign-owned banks are owned by the Nordic parent groups (SEB, Swedbank, DNB; 73.1\% of the sector's assets as of 2016) and AB "Citadele" bank is also a foreign subsidiary fully-owned by the parent bank. The bank subsidiaries and branches belonging to the Nordic parent groups account for $89.5 \%$ of the total banking sector assets and $91.4 \%$ of the total system lending, as of the end of 2016. Additionally, two local banks operated in the Lithuanian banking sector (AB Šiauliu bankas with the EBRD (18.2\%), AB Invalda Invl (6.8\%) and a private investor (5.8\%), and UAB Medicinos Bankas (the largest shareholder (private investor) holding an $89.9 \%$ stake)). 
Table 2. The Lithuanian banking sector: loan, deposit market shares, and growth in 2012-2016.

\begin{tabular}{cccccccc}
\hline & \multicolumn{3}{c}{$\begin{array}{c}\text { Banks Owned by the Nordic } \\
\text { Parent Group }\end{array}$} & $\begin{array}{c}\text { Foreign } \\
\text { Subsidiary }\end{array}$ & Local Banks & Branches \\
& Bank 1 & Bank 2 & Bank 3 & Bank 4 & Bank 5 & Bank 6 & Bank 7 \\
\hline Loans, billions $€$ & 5.4 & 4.6 & 2.9 & 0.3 & 1.0 & 0.1 & 3.6 \\
\% of total & 29.5 & 25.7 & 16.1 & 1.5 & 5.8 & 0.8 & 19.7 \\
Growth, \% (2012-2016) & 14.9 & 24.3 & 11.5 & 70.5 & 68.1 & 0.0 & 9.1 \\
Deposits, billions $€$ & 5.2 & 6.5 & 2.5 & 0.4 & 1.6 & 0.2 & 2.4 \\
\% of total & 27.5 & 34.5 & 13.2 & 2.2 & 8.3 & 1.2 & 12.6 \\
Growth, \% (2012-2016) & 40.5 & 51.2 & 47.1 & 88.7 & 154.0 & 0.0 & 33.3 \\
\hline
\end{tabular}

Source: Bank of Lithuania (2017a, 2017b, 2017c).

The majority of Lithuanian banks' income comes from loans (68\%), while deposits account for the largest share of liabilities ( $80 \%$, mostly current accounts). Bank profitability has been hit by the persistent low interest rate environment and the decline in fees and commissions following the introduction of the euro in early 2015, as banks lost income from currency exchanges and transfers as a result of the adoption of the common currency. However, banks in Lithuania earned the highest profits in five years and posting EUR 251.8 million in 2016 (a 17\% increase year-on-year). Profitability is increasing due to significantly decreased interest expenses and increased efficiency. The banks' efficiency ratio, which illustrates their cost-to-income ratio, was $47.8 \%$ in 2016. According to (Bank of Lithuania 2017c), the profitability and efficiency of banks in Lithuania are markedly higher if compared to the other banks operating in the EU. In the third quarter of 2016, the average value of the efficiency ratio of the EU banks was $63 \%$; of banks in Lithuania, $46 \%$; ROA, $0.6 \%$; and $1.2 \%$ respectively. Their ROE were $5.4 \%$ and $10.0 \%$, respectively.

To measure the Lithuanian banking sector's efficiency, we used the input-oriented DEA model under the VRS and the CRS assumptions. This model is frequently used in measuring banking efficiency (Diallo 2018; Paradi et al. 2018; Titko et al. 2014; Chen et al. 2013; Paradi and Zhu 2013; Cooper et al. 2011; Zhu 2009).

Table 3 summarises the statistical measures calculated for each individual bank in a sample. The Lithuanian bank's efficiency analysis based on VRS assumption shows (see Tables 3 and 4) that the best results demonstrate the local banks (in particular Bank 6). This result is quite interesting because during all the periods under analysis this bank did not demonstrate any exceptional growth outcomes. It is worth noting that during the given period, the banks owned by the Nordic parent group showed more technical inefficiency. The technical efficiency analysis based on the CRS assumption, where the technical efficiency can be divided into two parts: the pure technical efficiency and the scale efficiency shows other results: the banks owned by the Nordic parent group and the branches have higher pure efficiency than local banks, and have the success at working at the right scale. Based on that, it stated that during this period the larger Lithuanian banks (subsidiaries) applied a more appropriate business model than smaller (local) banks operating in Lithuania. At the same time, it should be noted that these differences between the CCR model (CRS) and the BCC model (VRS) could appear due to the fact that one of the local banks (Bank 5) acquired a significant part of the bankrupt bank's deposit and loan portfolio. The second reason is that during the financial crisis the largest Lithuanian banks suffered heavy losses that were amortized over the analyzed period. 
Table 3. Efficiency of Lithuanian banks calculated with M1-M5 models (respectively VRS (A) and CRS (B) assumptions): descriptive statistics.

\begin{tabular}{ccccccc}
\hline \multirow{2}{*}{ Bank } & & \multicolumn{2}{c}{ (A) } & & \\
\hline \multirow{2}{*}{ Banks owned by the } & Bank 1 & 0.8778 & 0.8952 & 0.3171 & 1.0000 & 0.0313 \\
Nordic parent group & Bank 2 & 0.9287 & 1.0000 & 0.5672 & 1.0000 & 0.0293 \\
& Bank 3 & 0.7903 & 1.0000 & 0.2080 & 1.0000 & 0.0546 \\
\hline Foreign subsidiary & Bank 4 & 0.8745 & 1.0000 & 0.6373 & 1.0000 & 0.0274 \\
\hline \multirow{2}{*}{ Local banks } & Bank 5 & 0.7680 & 0.7202 & 0.4526 & 1.0000 & 0.0425 \\
& Bank 6 & 0.9894 & 1.0000 & 0.8527 & 1.0000 & 0.0068 \\
\hline Branches & Bank 7 & 0.7029 & 0.6746 & 0.2253 & 1.0000 & 0.0469 \\
\hline Bank & & & (B) & & & \\
\hline \multirow{2}{*}{ Banks owned by the } & Bank 1 & 0.5951 & 0.6083 & 0.2872 & 0.8584 & 0.0300 \\
Nordic parent group & Bank 2 & 0.6106 & 0.5492 & 0.2570 & 1.0000 & 0.0430 \\
& Bank 3 & 0.6726 & 0.6862 & 0.1933 & 1.0000 & 0.0479 \\
\hline Foreign subsidiary & Bank 4 & 0.5588 & 0.5089 & 0.2282 & 1.0000 & 0.0521 \\
\hline \multirow{2}{*}{ Local banks } & Bank 5 & 0.4802 & 0.4713 & $0.0000 * *$ & 0.8727 & 0.0515 \\
& Bank 6 & 0.5045 & 0.4246 & $0.0000 * *$ & 1.0000 & 0.0765 \\
\hline Branches & Bank 7 & 0.7249 & 0.8365 & 0.1756 & 1.0000 & 0.0538 \\
\hline \multirow{2}{*}{ ** These banks have suffered losses in 2014. } & &
\end{tabular}

As one can note, the efficiency level was moderate: the average VRS efficiency was $86 \%$ and the average CRS efficiency was $60 \%$. These findings imply that an average bank should contract its inputs about $14-40 \%$ in order to operate efficiently. The lowest values of efficiency were $19 \%$. Additionally, the results suggest that during the research period, the banks' efficiency was quite unstable.

Production dimension. This dimension is represented by model 2, where the input is labor expenses and the output, loans. Based on what banking products banks produce using a different kind of resources, we choose loans as a main banking performance output. The loan portfolio is the main and the largest part of banks' assets and shows the banks' effectiveness to attract clients and manage risks. It should be noted that in this case the quality of loans was not assessed, i.e., the amount of non-performing loans has not been evaluated.

Efficiency analysis of production approach with BCC model shows that all banks are technically efficient with an average of $80 \%$. Model 2 indicates that foreign subsidiary banks (Bank 2, Bank 3, and Bank 4) work inefficiently and they can improve the efficiency through the proportional reduction of their inputs while their output proportions are held constant (they must better manage the labor cost or reconsider their business model). The average VRS efficiency of all these banks was only $58 \%$. The CCR model or the CRS efficiency shows the success of management at conversion input to output while scale efficiency shows the success at working at right scale. The CRS efficiency shows different results: all banks are technically efficient with an average of only $44 \%$. Two local banks and one foreign subsidiary (Bank 4, Bank 5, and Bank 6) are technically efficient with an average of $22 \%$. During the period of 2012-2016, the highest share of the banks (more than 50\%) operated under the sub-optimal scale (operating in the range of IRS (increasing returns to scale)). Therefore, the banks increased their scale size during 2012-2016, although there are still some possibilities to increase the share of banks operating under the most productive scale size. 
Profitability dimension. This dimension represents three models (M1, M3, and M5). Model M1 has two variables: deposits and the operating profit. The average VRS efficiency of all the Nordic banks was $97 \%$, a foreign bank subsidiary (Bank 4) reached the efficiency of $79 \%$, local banks, $85 \%$, and branches, only $60 \%$. The lowest value of efficiency was $22 \%$. The CRS efficiency shows that all banks are technically efficient with an average of $61 \%$ : all the Nordic banks was $56 \%$, a foreign bank subsidiary (Bank 4), 62\%, local banks, 77\%, and branches, $43 \%$. Furthermore, the local banks show better results than subsidiaries. Scale inefficiency in large banks may results from DRS (decreasing returns to scale) characteristics, because during that period banks owned by the Nordic parent group operating at the supra-optimal scale (DRS). This model shows that banks must improve their business model, as other operating incomes do not offset potential losses from the existing low interest rates on the market. 
Table 4. Average efficiency scores estimated for the Lithuanian banks using M1-M5 models and descriptive statistics of M1-M5 models.

\begin{tabular}{|c|c|c|c|c|c|c|c|c|c|c|c|c|c|c|c|c|}
\hline & & \multicolumn{3}{|c|}{ Profitability Dimension } & \multicolumn{3}{|c|}{ Production Dimension } & \multicolumn{3}{|c|}{ Profitability Dimension } & \multicolumn{3}{|c|}{ Intermediation Dimension } & \multicolumn{3}{|c|}{ Profitability Dimension } \\
\hline & & \multicolumn{3}{|c|}{ M1 } & \multicolumn{3}{|c|}{ M2 } & \multicolumn{3}{|c|}{ M3 } & \multicolumn{3}{|c|}{ M4 } & \multicolumn{3}{|c|}{ M5 } \\
\hline & & CRS & VRS & Scale Eff. & CRS & VRS & Scale Eff. & CRS & VRS & Scale Eff. & CRS & VRS & Scale Eff. & CRS & VRS & Scale Eff. \\
\hline Banks owned & Bank 1 & 0.4975 & 0.9036 & 0.5506 & 0.5489 & 1.0000 & 0.5489 & 0.6396 & 0.7292 & 0.8772 & 0.7377 & 1.0000 & 0.7377 & 0.5517 & 0.8246 & 0.6690 \\
\hline by the Nordic & Bank 2 & 0.5101 & 1.0000 & 0.5101 & 0.4365 & 0.6435 & 0.6783 & 1.0000 & 1.0000 & 1.0000 & 0.5313 & 0.6389 & 0.8315 & 0.5751 & 1.0000 & 0.5751 \\
\hline parent group & Bank 3 & 0.6818 & 1.0000 & 0.6818 & 0.4582 & 0.4828 & 0.9489 & 0.4085 & 0.4686 & 0.8717 & 0.9087 & 0.9156 & 0.9925 & 0.9060 & 1.0000 & 0.9060 \\
\hline $\begin{array}{c}\text { Foreign } \\
\text { subsidiary }\end{array}$ & Bank 4 & 0.6230 & 0.7919 & 0.7868 & 0.1789 & 0.6123 & 0.2922 & 0.2940 & 0.8793 & 0.3344 & 0.5072 & 0.8933 & 0.5677 & 0.7978 & 0.9126 & 0.8742 \\
\hline \multirow{2}{*}{ Local banks } & Bank 5 & 0.5322 & 0.7086 & 0.7510 & 0.3469 & 0.8760 & 0.3960 & 0.6456 & 0.8340 & 0.7741 & 0.4454 & 0.5215 & 0.8540 & 0.8237 & 0.8426 & 0.9776 \\
\hline & Bank 6 & 1.0000 & 1.0000 & 1.0000 & 0.1336 & 0.9471 & 0.1411 & 0.0924 & 1.0000 & 0.0924 & 0.4430 & 0.9971 & 0.4443 & 0.8535 & 1.0000 & 0.8535 \\
\hline Branches & Bank 7 & 0.4299 & 0.6004 & 0.7161 & 1.0000 & 1.0000 & 1.0000 & 0.6342 & 0.6786 & 0.9346 & 0.9557 & 0.9674 & 0.9879 & 0.6046 & 0.6154 & 0.9824 \\
\hline \multicolumn{2}{|l|}{ Mean } & 0.6106 & 0.8578 & 0.7138 & 0.4433 & 0.7945 & 0.5722 & 0.5306 & 0.7985 & 0.6978 & 0.6470 & 0.8477 & 0.7737 & 0.7303 & 0.8850 & 0.8340 \\
\hline \multicolumn{2}{|l|}{ Median } & 0.5567 & 1.0000 & 0.7111 & 0.3895 & 0.9129 & 0.5835 & 0.4939 & 0.9531 & 0.8864 & 0.5872 & 0.9479 & 0.8262 & 0.7439 & 1.0000 & 0.8727 \\
\hline \multicolumn{2}{|l|}{ Min } & 0.1756 & 0.2253 & 0.4360 & 0.0902 & 0.2080 & 0.0909 & 0.0000 & 0.3171 & 0.0000 & 0.3601 & 0.4096 & 0.3798 & 0.2660 & 0.2844 & 0.4895 \\
\hline \multicolumn{2}{|l|}{$\operatorname{Max}$} & 1.0000 & 1.0000 & 1.0000 & 1.0000 & 1.0000 & 1.0000 & 1.0000 & 1.0000 & 1.0000 & 1.0000 & 1.0000 & 1.0000 & 1.0000 & 1.0000 & 1.0000 \\
\hline \multicolumn{2}{|l|}{ StDev } & 0.0358 & 0.1990 & 0.1719 & 0.0494 & 0.0387 & 0.3310 & 0.0565 & 0.0402 & 0.3541 & 0.0365 & 0.0322 & 0.1999 & 0.0309 & 0.0281 & 0.1563 \\
\hline
\end{tabular}


Model M5 also has two variables: deposits and net interest income. This ratio represents the revenue that is generated from a bank's assets and the expenses associated with paying out its liabilities. The average VRS efficiency was $86 \%$ and all the banks operating in Lithuania seeks $90 \%$ efficiency (except for the branches: their VRS efficiency was only 66\%). CRS efficiency shows substantially similar results. Based on the results from this model, it can be stated that the Lithuanian banks managed to control low interest rates in the market, but looking to the future, however, bank managers should be more actively using value chain opportunities of other banks and differentiate their income (as M1 shows).

Model M3 consists of three variables: as input-deposits, and debts to banks and other credit institutions, and as output-profit before tax. This profit combines all of the bank's profits before tax, including operating, non-operating, continuing operations, and non-continuing operations.

It is interesting, that based on the results of this model, the banks owned by the Nordic parent group showed the worst results based on VRS efficiency: Bank 1 was only $73 \%$, Bank 3, 47\%, and the branches were efficient only by $68 \%$. Noteworthy, analyzed the CRS efficiency or pure technical efficiency, the worst results demonstrated two other banks (Bank 4 and Bank 6), respectively, 29\% and $9 \%$. High scale efficiency demonstrated by the banks owned by the Nordic parent group indicate the success to improve efficiency. During the period of 2012-2016, all these banks operated under the sub-optimal scale (operating in the range of IRS). This indicates, that local banks must proportionally reduce their inputs while their output proportions should be held constant. These findings imply that an average bank should contract its inputs about $60 \%$ in order to operate efficiently. The results of this model are closely related to the results of the previous models. We see that while banks are able to work effectively on the low interest rate market, they do not properly use other areas of their activity or inefficiently manage their other operational resources. Obviously, that banks need to adapt their business model to today's challenges since in the future they can not ensure sustainable activities.

Intermediation dimension. This dimension is represented by model 4 , where the input is deposits and the output, loans. This model best reflects the essential function of banks in the financial system: to be the financial intermediary, which leads to reallocation of funds among the participants in the financial system. Additionally, this model can show the possibilities of banks doing their business in the current low interest rate environment. The average VRS efficiency of two banks owned by the parent bank was $77 \%$, Bank 4, 89\%, and Bank 5, only 52\%. The CRS efficiency shows different results for Bank 1, Bank 4, and for Bank 6: all these banks are technically efficient with an average of only $56 \%$. The biggest banks (Bank 1, Bank 2, Bank 3, and Bank 7) are technically efficient with an average of 78\%, and the smallest (Bank 4, Bank 5, Bank 6), 46\%. During the period of 2012-2016, the highest share of the banks (more than 50\%) operated under the sub-optimal scale (operating in the range of IRS). This indicates that not all banks were able to adapt to the challenging business environment or discover new opportunities for more efficient use of the available resources and more active management of the differences in interest rates between different types of assets and liabilities.

Cooper et al. (2011) suggest validating the results obtained using the DEA method. They propose to compare the DEA results with the bank's own performance measures. Based on that, we selected the main bank profitability measure-the return on assets ratio (ROA) - and compared it with the results obtained from two DEA models (M3 and M5) with the CRS and the VRS assumptions (see Figure 1). These models also present the efficiency based on profitability dimension. M3 model (especially with CRS assumption) showed a very close movement compared to ROA. Additionally, this model has the largest adjusted $\mathrm{R}^{2}$ (regression coefficient is statistically significant at 0.05 level). Model 5 presented better results than the ROA ratio. This model, as an output, has a net interest income and showed high efficiency managing the interest rate differences in today's low interest rate environment. 


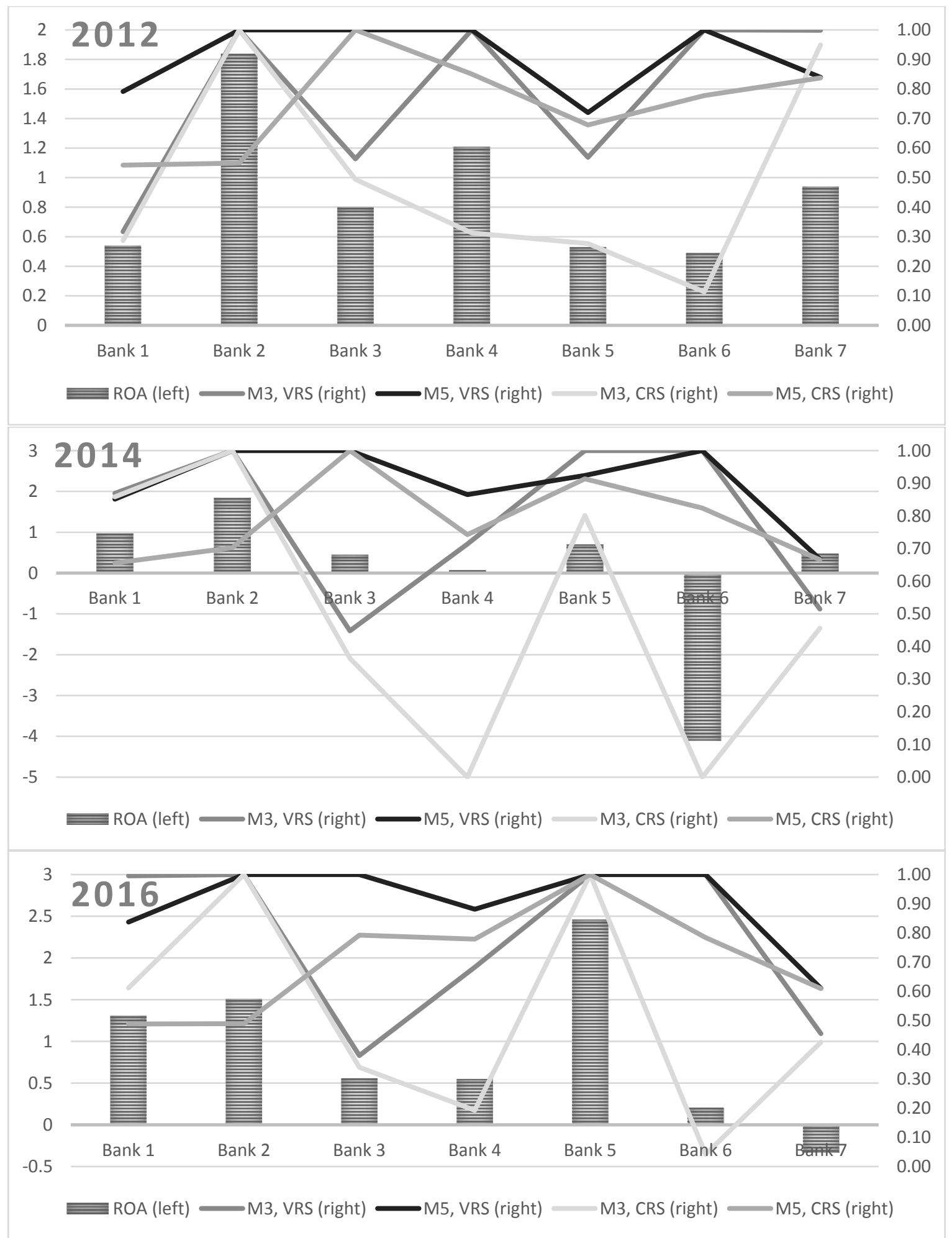

Figure 1. Relationship between ROA ratio and efficiency (M3 and M5 models with the VRS and the CRS assumptions).

\section{Discussion}

The main problem addressed in the study is the efficiency of the financial sector, especially the banking sector, which is potentially important for the long-term economic growth. While the 
empirical evidence suggested that foreign-owned banks in the developing and transition countries have succeeded in capitalizing on their advantages and exhibit a higher level of efficiency compared to their domestic bank peers, the study showed some different results in Lithuania. The analysis of the Lithuanian banks' efficiency showed better results for local banks, meanwhile, the banks owned by the Nordic parent group showed more inefficiency based on the VRS assumption (especially in M2 and M3). The pure technical efficiency and the scale efficiency analysis show that foreign subsidiaries demonstrate better efficiency and reflects the success of a bank management during the 2012-2016.

All banks operating in Lithuania belong to different risk management systems. The Lithuanian subsidiaries are also supervised by the European Central Bank, while the parent banks-all headquartered outside the eurozone-are overseen by the Swedish or Norwegian regulators. This may imply the need for a more detailed analysis of the financial risk management systems across Europe and connect it with the bank efficiency level.

Further research should also include the banking sector from all the Baltic States, where the conditions for the development of the banking sector after the restoration of the independence of the Baltic countries (Estonia, Latvia, and Lithuania) were identical. The European Commission treats the Baltic States as the integrated Baltic economy, i.e., an area driven for a sizeable part by common factors and economic links. Yet, there are also asymmetries, with Estonia being the most exposed to international developments, Latvia being less influenced by regional spillovers, and Lithuania being a much less influential driver. It would be useful to investigate how those asymmetries influence the banking sector efficiency level in different countries.

\section{Conclusions}

Foreign capital banks, registered in Lithuania, have a significantly higher market share of assets, liabilities, loans, and deposits among the Lithuanian commercial banks. Assets and liabilities in the Lithuanian capital banks grew at a slower pace than in foreign capital banks. The share of liabilities in total assets in the Lithuanian capital banks has decreased, while it has increased in foreign capital banks.

To measure the Lithuanian banking sector's efficiency used the input-oriented DEA model under the VRS and the CRS assumptions. The Lithuanian bank's efficiency analysis based on VRS assumption shows that better results demonstrate the local banks. The technical efficiency analysis based on the CRS assumption, where the technical efficiency can be divided into two parts-the pure technical efficiency and the scale efficiency shows other results: the banks owned by the Nordic parent group and the branches have higher pure efficiency than local banks and have the success at working at right scale. Based on that, it stated that during this period the larger Lithuanian banks (subsidiaries) applied a more appropriate business model than smaller (local) banks operating in Lithuania.

The performance of banks and bank branches are analyzed along three dimensions: production, profitability, and intermediation. Efficiency analysis on production approach with the BCC model shows that all banks are technically efficient with an average of $80 \%$. The CRS efficiency shows different results: all banks are technically efficient with an average of only $44 \%$.

The profitability dimension represents three models (M1, M3, and M5) and, based on the results from this model, it can be stated, that the Lithuanian banks managed to control low interest rates in the market, but looking to the future, however, bank managers should be more actively using value chain opportunities of other banks and differentiate their income.

The intermediation dimension is represented by model 4 and shows that not all banks were able to adapt to the challenging business environment or discover new opportunities for more efficient use of the available resources and more active management of the differences in interest rates between different types of assets and liabilities.

Nevertheless, the continuing unfavorable low interest environment is likely to have a negative effect on the performance of banks due to low earnings, which depends on the difference between short-term and long-term interest rates. In addition, banks are closely linked to the economy of the 
country in which they operate; so as long as economic growth remains low in Europe, it is unlikely that the banks' performance will improve, if significant operational changes are not made.

Consequently, the current challenges in the market force the transformation of the banking model, and the increase in lending volumes, the current low cost of financial resources, the digitisation of bank services, the potential benefits of a more efficient use of the existing structure, and the consolidation of individual activities would increase the profitability of banks. It is obvious that the current situation where banks operate without changing their business model in a low-inflation (and interest rate) environment reduces bank profits, which, in turn, negatively affects the value of banks, as investors are more concerned about bank profitability than solvency indicators (stress-based stress testing in the long run).

Author Contributions: The contribution to the article is distributed as follows: L. Novickyte $-60 \%$, J. Droždz-40\%. L. Novickyte and J. Droždz conducted the theoretical analysis, selected the system of methods, and prepared the structure of the paper. L. Novickyte collected data and developed models. L. Novickyte and J. Droždz interpreted the data, and prepared the discussions and conclusions of the paper. J. Droždz compiled a list of references.

Conflicts of Interest: The authors declare no conflict of interest. The founding sponsors had no role in the design of the study; in the collection, analyses, or interpretation of data; in the writing of the manuscript; or in the decision to publish the results.

\section{References}

Andersson, Fredrik N. G., Katarzyna Burzynska, and Sonja Opper. 2016. Lending for Growth? A Granger Causality Analysis of China's Finance-Growth Nexus. Empirical Economics 51: 897-920. [CrossRef]

Asmild, Mette, and Minyan Zhu. 2016. Controlling for the use of extreme weights in bank efficiency assessments during the financial crisis. European Journal of Operational Research 251: 999-1015. [CrossRef]

Association of Lithuanian Banks. 2017. General Information on Banking Sector; The Association of Lithuanian Banks. Available online: http:/ / www.lba.lt/en/general-information-on-banking-sector (accessed on 20 December 2017).

Balkevicius, Artūras. 2012. Influence of the Financial Sector on Economic Development. Business Systems and Economics 2: 82-94.

Bank of Lithuania. 2017a. Main Indicators of Banking Sector Activities; The Bank of Lithuania. Available online: https://www.lb.lt/en/main-indicators-of-banking-sector-activities (accessed on 20 December 2017).

Bank of Lithuania. 2017b. Consolidated Main Indicators of Banking Activities; The Bank of Lithuania. Available online: https://www.lb.lt/en/consolidated-main-indicators-of-banking-activities (accessed on 20 December 2017).

Bank of Lithuania. 2017c. Banking Activity Reviews; The Bank of Lithuania. Available online: https://www. lb.lt/en/publications?category $\% 5 \mathrm{~B} 0 \% 5 \mathrm{D}=39 \&$ series $\% 5 \mathrm{~B} 0 \% 5 \mathrm{D}=171 \&$ theme $\% 5 \mathrm{~B} 0 \% 5 \mathrm{D}=334$ (accessed on 20 December 2017).

Banerjee, Prashanta Kumar, Nehal Ahmed, and Mosharref Hossain. 2017. Bank, stock market and economic growth: Bangladesh perspective. Journal of Developing Areas 51: 17-29. [CrossRef]

Banker, Rajiv D., Abraham Charnes, and William W. Cooper. 1984. Some models for estimating technical and scale efficiencies in data envelopment analysis. Management Science 30: 1078-92. [CrossRef]

Belke, Ansgar, Ulrich Haskamp, and Ralph Setzer. 2016. Regional Bank Efficiency and Its Effect on Regional Growth in 'Normal' and 'Bad' Times. Economic Modelling 58: 413-26. [CrossRef]

Cevik, Nuket Kirci, Sel Dibooglu, and Ali M. Kutan. 2016. Real and Financial Sector Studies in Central and Eastern Europe: A Review. Czech Journal of Economics and Finance 66: 2-31.

Charnes, Abraham, and William W. Cooper. 1962. Programming with linear fractional functional. Naval Research Logistics 9: 181-86. [CrossRef]

Charnes, Abraham, William W. Cooper, and Edwardo Rhodes. 1978. Measuring the efficiency of decision making units. European Journal of Operational Research 2: 429-44. [CrossRef]

Chen, Yu-Chuan, Yung-Ho Chiu, Chin-Wei Huang, and Chien Heng Tu. 2013. The analysis of bank business performance and market risk-Applying Fuzzy DEA. Economic Modelling 32: 225-32. [CrossRef]

Cook, Wade D., Kaoru Tone, and Joe Zhu. 2014. Data envelopment analysis: Prior to choosing a model. Omega 44: 1-4. [CrossRef] 
Cooper, William W., Lawrence M. Seiford, and Kaoru Tone. 2007. Data Envelopment Analysis: A Comprehensive Text with Models, Applications, References and DEA-Solver Software, 2nd ed. Cham: Springer International Publishing AG, ISBN 10-0-387-45281-8.

Cooper, William W., Lawrence M. Seiford, and Joe Zhu. 2011. Handbook on Data Envelopment Analysis, 2nd ed. Cham: Springer International Publishing AG, ISBN 978-1-4419-6150-1.

Cvetkoska, Violeta, and Gordana Savić. 2017. Efficiency of bank branches: empirical evidence from a two-phase research approach. Economic Research-Ekonomska Istraživanja 30: 318-33. [CrossRef]

Cvilikas, Aurelijus, and Edita Jurkonyte-Dumbliauskiene. 2016. Assessment of Risk Management Economic Efficiency Applying Economic Logistic Theory. Transformations in Business \& Economics 15: 207-19.

Destefanis, Sergio, Christian Barra, and Lubrano G. Lavadera. 2014. Financial Development and Local Growth: Evidence from Highly Disaggregated Italian Data. Applied Financial Economics 24: 1605-15. [CrossRef]

Diallo, Boubacar. 2018. Bank efficiency and industry growth during financial crises. Economic Modelling 68: 11-22. [CrossRef]

Drucker, Peter F. 1963. Managing for business effectiveness. Harvard Business Review 41: 53-60.

Farrell, Michael J. 1957. The measurement of productive efficiency. Journal of the Royal Statistical Society 120: 253-90. [CrossRef]

Ferreira, Cândida. 2012. Bank Efficiency, Market Concentration and Economic Growth in the European Union. Working Papers; Lisbon: ISEG-Lisbon School of Economics and Management, Department of Economics, Universidade de Lisboa.

Fethi, Meryem Duygun, and Fotios Pasiouras. 2010. Assessing bank efficiency and performance with operational research and artificial intelligence techniques: A survey. European Journal of Operational Research 204: 189-98. [CrossRef]

Fung, Michael K., and Arnold C. S. Cheng. 2010. Convergence of total factor productivity among banks: Hong Kong's experience. Global Finance Journal 21: 201-10. [CrossRef]

Kutsomanoli-Filippaki, Anastasia, Dimitris Margaritis, and Christos Staikouras. 2009. Efficiency and Productivity Growth in the Banking Industry of Central and Eastern Europe. Journal of Banking E Finance 33: 557-67.

Paradi, Joseph C., David H. Sherman, and Fai Keung Tam. 2018. Data Envelopment Analysis in the Financial Services Industry: A Guide for Practitioners and Analysts Working in Operations Research Using DEA. Cham: Springer International Publishing AG, ISBN 978-3-319-69723-9.

Paradi, Joseph C., and Haiyan Zhu. 2013. A survey on bank branch efficiency and performance research with data envelopment analysis. Omega 41: 61-79. [CrossRef]

Roghanian, Parastoo, Amran Raslia, and Hamed Gheysari. 2012. Productivity through Effectiveness and Efficiency in the Banking Industry. Procedia-Social and Behavioral Sciences 40: 550-56. [CrossRef]

Sufian, Fadzlan, Fakarudin Kamarudin, and Annuar Nassir. 2016. Determinants of efficiency in the Malaysian banking sector: Does bank origins matter? Intellectual Economics 10: 38-54. [CrossRef]

Titko, Jelena, Jelena Stankevičienè, and Natalja Lace. 2014. Measuring bank efficiency: DEA application. Technological and Economic Development of Economy 20: 739-57. [CrossRef]

Tuškan, Branka, and Alen Stojanović. 2016. Measurement of cost efficiency in the European banking industry Croatian. Operational Research Review 7: 47-66.

Waheed, Abdul, and Najia Younus. 2010. Effects of Financial Sector's Development and Financial Sector's Efficiency on Economic Growth: Empirical Evidence from Developing and Developed Countries. International Journal of Economic Perspectives 4: 449-58.

Zhang, Ling, Sheng Zhang, and Na Tao. 2016. Financial System Risk Tolerance Capacity and Economic Growth: Evidence from a Cross-Country Analysis. Global Economic Review 45: 97-115. [CrossRef]

Zhu, Joe. 2009. Quantitative Models for Performance Evaluation and Benchmarking Data Envelopment Analysis with Spreadsheets, 2nd ed. Cham: Springer International Publishing AG, ISBN 13-978-0-387-85981-1.

(C) 2018 by the authors. Licensee MDPI, Basel, Switzerland. This article is an open access article distributed under the terms and conditions of the Creative Commons Attribution (CC BY) license (http://creativecommons.org/licenses/by/4.0/). 